Article

\title{
Polyoxygenated Cembrane Diterpenoids from the Soft Coral Sarcophyton ehrenbergi
}

\author{
Shi-Yie Cheng ${ }^{1}$, Shang-Kwei Wang ${ }^{2}$, Mu-Keng Hsieh ${ }^{3}$ and Chang-Yih Duh ${ }^{3,4, *}$ \\ 1 Department of Life Sciences, National University of Kaohsiung, Kaohsiung 811, Taiwan; \\ E-Mail: shiyie@nuk.edu.tw \\ 2 Department of Microbiology, Kaohsiung Medical University, Kaohsiung 807, Taiwan; \\ E-Mail: skwang@cc.kmu.edu.tw \\ 3 Department of Marine Biotechnology and Resources, National Sun Yat-sen University, \\ Kaohsiung 804, Taiwan; E-Mail: qaz7824780@yahoo.com.tw \\ 4 Graduate Institute of Natural Products, Kaohsiung Medical University, Kaohsiung 807, Taiwan \\ * Author to whom correspondence should be addressed; E-Mail: yihduh@mail.nsysu.edu.tw; \\ Tel.: +886-7-525-2000 (ext. 5036).
}

Academic Editor: Vladimír Křen

Received: 27 February 2015 / Accepted: 11 March 2015 / Published: 17 March 2015

\begin{abstract}
Five new polyoxygenated cembranoids, named (+)-1,15-epoxy-2-methoxy-12methoxycarbonyl-11E-sarcophytoxide (1), (+)-2-epi-12-methoxycarbonyl-11E-sarcophine (2), 3,4-epoxyehrenberoxide A (3), ehrenbergol D (4) and ehrenbergol E (5), were obtained from the soft coral Sarcophyton ehrenbergi. The structures of 1-5 were established on the basis of comprehensive NMR and HR-ESI-MS analyses and by comparison with reported data in the literature. Compounds $\mathbf{4}$ and $\mathbf{5}$ showed moderate cytotoxicity against P-388 (mouse lymphocytic leukemia) cancer cell line with $\mathrm{EC}_{50}$ values of 2.0 and $3.0 \mu \mathrm{M}$, respectively. Compound $\mathbf{2}$ exhibited slight antiviral activity against HCMV (human cytomegalovirus) with $\mathrm{IC}_{50}$ values of $25.0 \mu \mathrm{g} / \mathrm{mL}$.
\end{abstract}

Keywords: polyoxygenated cembranoids; Sarcophyton ehrenbergi; cytotoxicity; HCMV (human cytomegalovirus) 


\section{Introduction}

Sarcophyton ehrenbergi (von Marenzeller, 1886), ordinarily regarded as the leather coral, belongs to the order Alcyonacea, and is classified as an octocoral because of eight-fold symmetry or eight-branched tentacles in their polyp structure. From a chemical perspective, the alcyonacean soft coral $S$. ehrenbergi is interesting due to macrocyclic cembranoids with intriguing structural features and various promising biological activities [1-7]. In the course of our ongoing research focused toward the purification of bioactive metabolites from the organism, several polyoxygenated cembrane-type diterpenoids were discovered. Some of the obtained metabolites have been proven to exhibit antiviral and cytotoxic properties [4-6]. The two soft corals form our previous studies on the bioactive metabolites of $S$. ehrenbergi were collected at the Dongsha atoll and San-Hsian-Tai island, respectively. The comparative results revealed that the two samples collected from the different habitat might have different secondary metabolites even though they are supposed to be the same species. Apparently, some of these obtained cembranoids are able to be produced or modified through their symbiosis with zooxanthellae [8].

In view of the bioactive potential of macrocyclic cembrane-type diterpenoids, our continuing chemical investigations of $S$. ehrenbergi, collected at San-Hsian-Tai island (Taitong County), have resulted in the purification of five new polyoxygenated cembranoids $\mathbf{1 - 5}$ (Figure 1) from the acetone-soluble fraction of the organism. The structures of these obtained metabolites were elucidated through extensive spectroscopic analyses, including 2D NMR spectroscopy [correlation spectroscopy (COSY), heteronuclear single-quantum correlation (HSQC), heteronuclear multiple bond coherence (HMBC) and nuclear overhauser effect spectroscopy (NOESY)], and by comparison of the spectroscopic data with those of related known compounds [4-7]. Moreover, compounds 1-5 were evaluated in vitro for cytotoxicity against P-388 (mouse lymphocytic leukemia), A-459 (human lung carcinoma), HT-29 (human colon adenocarcinoma), and HEL (human embryonic lung) cells, and antiviral activity against HCMV (human cytomegalovirus).
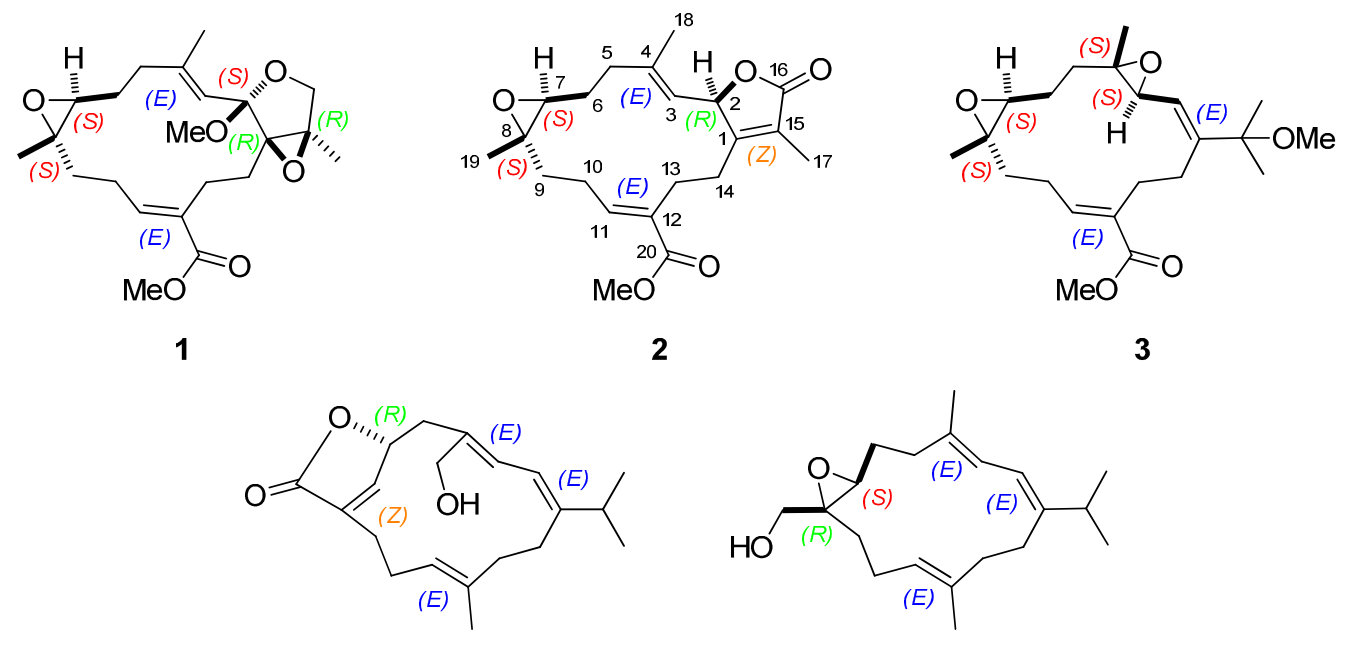

4

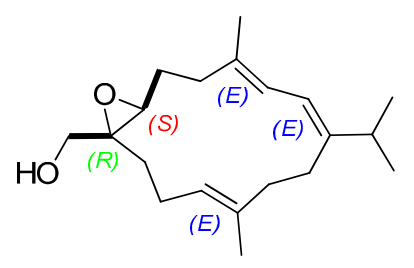

5

Figure 1. The structures of $(+)$-1,15-epoxy-2-methoxy-12-methoxycarbonyl-11Esarcophytoxide (1), (+)-2-epi-12-methoxycarbonyl-11E-sarcophine (2), 3,4-epoxyehrenberoxide A (3), ehrenbergol D (4) and ehrenbergol E (5). 


\section{Results and Discussion}

Specimens of $S$. ehrenbergi were stored in a freezer until extraction. Conventional extraction procedures were used, and the acetone extract was exhaustively partitioned between EtOAc and $\mathrm{H}_{2} \mathrm{O}$ to afford the EtOAc-soluble fraction, which was evaporated under vacuum to yield a dark brown gum (46.9 g). The concentrated residue was subjected to column chromatography and high-performance liquid chromatography, leading to the purification of compounds $\mathbf{1}-\mathbf{5}$.

(+)-1,15-Epoxy-2-methoxy-12-methoxycarbonyl-11E-sarcophytoxide (1) had a high resolution electrospray ionization mass spectrometry (HRESIMS) sodiated molecular ion peak at $\mathrm{m} / \mathrm{z} 415.2093$ $[\mathrm{M}+\mathrm{Na}]^{+}$, corresponding to the molecular formula $\mathrm{C}_{22} \mathrm{H}_{32} \mathrm{O}_{6}$ with seven indices of hydrogen deficiency. The IR spectrum of 1 showed a strong absorption band at $1712 \mathrm{~cm}^{-1}$, indicating the presence of an $\alpha, \beta$-unsaturated methyl ester carbonyl group, as well as from the UV absorption $(\mathrm{MeOH}) \lambda_{\max }(\log \varepsilon)$ at 225 (3.83) $\mathrm{nm}$ [4]. This functionality was further identified by the ${ }^{1} \mathrm{H}$ NMR signals (Table 1 ) at $\delta_{\mathrm{H}} 6.85$ $(1 \mathrm{H}, \mathrm{dd}, J=10.0,6.8 \mathrm{~Hz})$ and ${ }^{13} \mathrm{C}$ NMR signals (Table 2) at $\delta_{\mathrm{C}} 167.4$ (qC, C-20), 133.8 (qC, C-12) and $141.4(\mathrm{CH}, \mathrm{C}-11)$. Comparison of the NMR spectroscopic data (Tables 1 and 2) coupled with ${ }^{1} \mathrm{H}-{ }^{1} \mathrm{H}$ COSY, HSQC and HMBC correlations (Figure 2) of 1 with those of lobophynin C [4], suggested that 1 was established to be an 1,15-epoxy-2-methoxylated analogue of lobophynin $\mathrm{C}$, coinciding with methoxy protons at $\delta_{\mathrm{H}} 3.18(3 \mathrm{H}, \mathrm{s})$ correlated to a ketal carbon resonating at $\delta_{\mathrm{C}} 107.1(\mathrm{qC}, \mathrm{C}-2)$, and methyl protons at $\delta \mathrm{H} 1.11(3 \mathrm{H}, \mathrm{s}, \mathrm{Me}-17)$ correlated to the quaternary oxycarbons at $\delta \mathrm{c} 71.7(\mathrm{qC}, \mathrm{C}-1)$ and 64.6 (qC, C-15) in its HMBC spectrum.
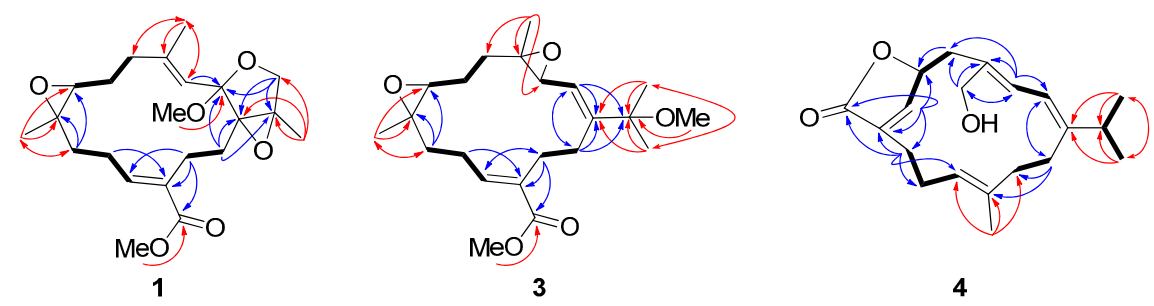

Figure 2. Selected ${ }^{1} \mathrm{H}^{-1} \mathrm{H} \operatorname{COSY}(-)$ and $\operatorname{HMBC}(\rightarrow)$ correlations of $\mathbf{1 ,} \mathbf{3}$ and $\mathbf{4}$.

The relative stereochemistry of $\mathbf{1}$ was facilitated by the NOESY correlations and previously reported X-ray crystallographic data of (+)-12-carboxy-11E-sarcophytoxide [4]. The absence of a NOESY correlation (Figure 3) between the vinylic $\mathrm{H}-11$ and $\mathrm{H}_{2}-13$ made it possible to identify the configuration of the olefin at C-11/C-12 as $E$ geometry, which was also confirmed by the chemical shift of $\mathrm{H}-11$ at $\delta_{\mathrm{H}} 6.85$ [9]. The geometry of the trisubstituted olefin at C-3 and C-4 was assigned as $E$ based on the $\gamma$-effect of the olefinic methyl signal for $\mathrm{CH}_{3}-18(<20 \mathrm{ppm})$ [10]. Moreover, the crucial NOESY correlations (Figure 3 ) between H-3/2-OMe, H-3/H-5b ( $\left.\delta_{\mathrm{H}} 1.95\right), \mathrm{H}-3 / \mathrm{H}-14 \mathrm{~b}\left(\delta_{\mathrm{H}} 1.96\right)$, H-7/Me-18, H-7/H-9a ( $\left.\delta_{\mathrm{H}} 1.85\right)$, H-7/H-6a ( $\left.\delta_{\mathrm{H}} 2.00\right)$, Me-19/H-9b ( $\left.\delta_{\mathrm{H}} 0.96\right)$, Me-19/H-6b ( $\left.\delta_{\mathrm{H}} 1.22\right)$, $\mathrm{H}-11 / \mathrm{H}-10 \mathrm{~b}\left(\delta_{\mathrm{H}} 1.79\right), \mathrm{H}-13 \mathrm{~b}\left(\delta_{\mathrm{H}} 2.49\right) / \mathrm{H}-14 \mathrm{a}\left(\delta_{\mathrm{H}} 2.25\right)$, and $\mathrm{H}-14 \mathrm{a} / \mathrm{Me}-17$ demonstrated the $1 R^{*}, 2 S^{*}$, $7 S^{*}, 8 S^{*}$ and $15 R^{*}$ configurations. By correlation with ehrenberoxides on the biogenetic consideration, the absolute configurations of the key chiral carbons in $\mathbf{1}$ could be proposed as depicted in Figure 1. Our result presented here has added further support to this conclusion that almost all cembrane diterpenes of known absolute configuration at C-1 reported from the order Alcyonacea possess the $R$-configuration [11,12]. 
The HRESIMS spectrum exhibited a sodiated molecular ion peak at $m / z 383.1832[\mathrm{M}+\mathrm{Na}]^{+}$for 2 identical to that of (+)-12-methoxycarbonyl-11E-sarcophine [4]. Comprehensive analysis of 2D NMR data, comprising COSY, HMQC and HMBC experiments, enabled the complete planar structure of 2 , the same as that of lobophynin C. The crucial NOESY correlations between $\mathrm{H}-7 / \mathrm{H}-6 \mathrm{a}\left(\delta_{\mathrm{H}} 2.21\right)$, Me-19/H-6b ( $\left.\delta_{\mathrm{H}} 1.47\right), \mathrm{H}-7 / \mathrm{H}-9 \mathrm{a}\left(\delta_{\mathrm{H}} 2.19\right)$, and Me-19/H-9b $\left(\delta_{\mathrm{H}} 1.08\right)$ indicated the same disposition of the epoxide at $\mathrm{C}-7$ and $\mathrm{C}-8$ as in the case of 1 . Owing to the remarkable chemical shift changes of $\mathrm{H}-2, \mathrm{H}-3$ and $\mathrm{H}_{3}-18\left(\delta_{\mathrm{H}} 5.57,5.08\right.$, and 1.87 , respectively in $\mathrm{CDCl}_{3}$ of $(+)-12$-methoxycarbonyl-11Esarcophine), we assume that the only variety between 2 and (+)-12-methoxycarbonyl-11E-sarcophine is the different orientation of the $\alpha, \beta$-unsaturated $\gamma$-lactone ring fused to the 14-membered ring at C-2. The CD spectrum of 2 exhibited a positive Cotton effect around $\lambda_{\max }(\Delta \varepsilon) 279(+6.8) \mathrm{nm}$ and a negative Cotton effect around $\lambda_{\max }(\Delta \varepsilon) 245(-1.1)$ and $215(-2.9) \mathrm{nm}$, suggesting the $R$-configuration at C-2 [13]. Hence, compound 2 was assigned as (+)-2-epi-12-methoxycarbonyl-11E-sarcophine.

Table 1. ${ }^{1} \mathrm{H}$ NMR spectroscopic data of compounds $\mathbf{1}-\mathbf{5}$.

\begin{tabular}{|c|c|c|c|c|c|}
\hline No. & $1^{a}$ & $2^{b}$ & $3^{a}$ & $4^{a}$ & $5^{b}$ \\
\hline 2 & - & $5.48 \mathrm{~d}(9.2)^{c}$ & $5.43 \mathrm{~d}(8.4)^{c}$ & $5.89 \mathrm{~d}(11.2)^{c}$ & $6.07 \mathrm{~d}(10.8)^{c}$ \\
\hline 3 & $5.33 \mathrm{~s}$ & $5.22 \mathrm{~d}(9.2)$ & $3.53 \mathrm{~d}(8.4)$ & $6.29 \mathrm{~d}(11.2)$ & $5.98 \mathrm{~d}(10.8)$ \\
\hline \multirow{2}{*}{5} & a: $2.03 \mathrm{~m}$ & a: $2.54 \mathrm{~m}$ & a: 2.02 ddd $(14.0,5.6,2.8)$ & a: $2.87 \mathrm{~m}$ & a: $2.28 \mathrm{~m}$ \\
\hline & b: $1.95 \mathrm{~m}$ & b: $2.19 \mathrm{~m}$ & $\mathrm{~b}: 1.08 \mathrm{~m}$ & b: $2.83 \mathrm{~m}$ & $\mathrm{~b}: 2.24 \mathrm{~m}$ \\
\hline \multirow{2}{*}{6} & $\mathrm{a}: 2.00 \mathrm{~m}$ & $\mathrm{a}: 2.21 \mathrm{~m}$ & $\mathrm{a}: 1.83 \mathrm{~m}$ & $5.19 \mathrm{~m}$ & $\mathrm{a}: 1.85 \mathrm{~m}$ \\
\hline & $\mathrm{b}: 1.22 \mathrm{~m}$ & b: $1.47 \mathrm{~m}$ & $\mathrm{~b}: 1.16 \mathrm{~m}$ & - & $\mathrm{b}: 1.79 \mathrm{~m}$ \\
\hline 7 & $2.74 \mathrm{dd}(10.0,3.6)^{c}$ & $2.57 \mathrm{~m}$ & $2.74 \mathrm{dd}(10.8,3.6)$ & $6.83 \mathrm{br} \mathrm{s}$ & $3.01 \mathrm{dd}(6.0,5.6)$ \\
\hline \multirow{2}{*}{9} & a: $1.85 \mathrm{~m}$ & $\mathrm{a}: 2.19 \mathrm{~m}$ & a: $1.91 \mathrm{~m}$ & $\mathrm{a}: 2.52 \mathrm{~m}$ & a: $2.18 \mathrm{~m}$ \\
\hline & b: $0.96 \mathrm{dd}(16.4,9.6)$ & b: $1.08 \mathrm{~m}$ & b: $0.80 \mathrm{t}(12.4)$ & $\mathrm{b}: 2.04 \mathrm{~m}$ & $\mathrm{~b}: 1.61 \mathrm{~m}$ \\
\hline \multirow{2}{*}{10} & $\mathrm{a}: 2.09 \mathrm{~m}$ & $\mathrm{a}: 2.59 \mathrm{~m}$ & $\mathrm{a}: 1.84 \mathrm{~m}$ & $\mathrm{a}: 2.31 \mathrm{~m}$ & $\mathrm{a}: 2.18 \mathrm{~m}$ \\
\hline & $\mathrm{b}: 1.79 \mathrm{~m}$ & $\mathrm{~b}: 2.17 \mathrm{~m}$ & b: $1.65 \mathrm{tt}(12.4,6.0)$ & $\mathrm{b}: 2.18 \mathrm{~m}$ & $\mathrm{~b}: 2.04 \mathrm{~m}$ \\
\hline 11 & $6.85 \mathrm{dd}(10.0,6.8)$ & $6.80 \mathrm{dd}(8.8,6.4)$ & $6.83 \mathrm{dd}(10.4,6.4)$ & 4.66 br d (10.4) & 5.08 br t (6.4) \\
\hline \multirow{2}{*}{13} & a: $2.64 \operatorname{td}(13.6,6.4)$ & $\mathrm{a}: 2.55 \mathrm{~m}$ & a: $2.56 \operatorname{td}(12.8,4.8)$ & $\mathrm{a}: 2.22 \mathrm{~m}$ & $2.04 \mathrm{~m}$ \\
\hline & b: $2.49 \operatorname{td}(13.6,3.6)$ & $\mathrm{b}: 2.37 \mathrm{~m}$ & b: $2.40 \operatorname{td}(12.8,4.8)$ & $\mathrm{b}: 2.07 \mathrm{~m}$ & - \\
\hline \multirow{2}{*}{14} & a: $2.25 \operatorname{td}(13.6,6.4)$ & $2.19 \mathrm{~m}$ & a: $2.28 \operatorname{td}(12.8,4.8)$ & $\mathrm{a}: 2.68 \mathrm{~m}$ & $2.29 \mathrm{~m}$ \\
\hline & b: $1.96 \mathrm{~m}$ & - & b: $2.19 \operatorname{td}(12.8,4.8)$ & b: $1.98 \mathrm{~m}$ & - \\
\hline 15 & - & - & - & - & $2.35 \mathrm{~m}$ \\
\hline \multirow{2}{*}{16} & a: $3.68 \mathrm{~d}(10.0)$ & - & $1.32 \mathrm{~s}$ & $1.05 \mathrm{~d}(6.8)$ & $1.06 \mathrm{~d}(6.4)$ \\
\hline & b: $3.38 \mathrm{~d}(10.0)$ & - & - & - & - \\
\hline 17 & $1.11 \mathrm{~s}$ & $1.92 \mathrm{~s}$ & $1.39 \mathrm{~s}$ & $1.14 \mathrm{~d}(6.8)$ & $1.07 \mathrm{~d}(6.4)$ \\
\hline \multirow{2}{*}{18} & $2.00 \mathrm{~s}$ & $1.96 \mathrm{~s}$ & $1.12 \mathrm{~s}$ & a: $4.09 \mathrm{~d}(13.6)$ & $1.76 \mathrm{~s}$ \\
\hline & - & - & - & b: $4.03 \mathrm{~d}(13.6)$ & - \\
\hline \multirow{2}{*}{19} & $1.04 \mathrm{~s}$ & $1.31 \mathrm{~s}$ & $0.93 \mathrm{~s}$ & - & a: $3.77 \mathrm{dd}(12.0,6.4)$ \\
\hline & - & - & - & - & b: $3.56 \mathrm{dd}(12.0,4.8)$ \\
\hline 20 & - & - & - & $1.51 \mathrm{~s}$ & $1.59 \mathrm{~s}$ \\
\hline 2-OMe & $3.18 \mathrm{~s}$ & - & - & - & - \\
\hline $15-\mathrm{OMe}$ & & - & $2.93 \mathrm{~s}$ & - & - \\
\hline 20-OMe & $3.40 \mathrm{~s}$ & $3.77 \mathrm{~s}$ & $3.40 \mathrm{~s}$ & - & - \\
\hline $19-\mathrm{OH}$ & - & - & - & - & $1.62 \mathrm{~m}$ \\
\hline
\end{tabular}

${ }^{a}$ Spectra were measured in $\mathrm{C}_{6} \mathrm{D}_{6}(400 \mathrm{MHz}) ;{ }^{b}$ Spectra were measured in $\mathrm{CDCl}_{3}(400 \mathrm{MHz}) ;{ }^{c} J$ values (in $\mathrm{Hz}$ ) are in parentheses. 
Table 2. ${ }^{13} \mathrm{C}$ NMR spectroscopic data of compounds $\mathbf{1}-\mathbf{5}$.

\begin{tabular}{|c|c|c|c|c|c|}
\hline No. & $1^{a}$ & $2^{b}$ & $3^{a}$ & $4^{b}$ & $5^{b}$ \\
\hline 1 & $71.7(\mathrm{qC})^{c}$ & $161.1(\mathrm{qC})^{c}$ & $148.8(\mathrm{qC})^{c}$ & $149.3(\mathrm{qC})^{c}$ & $148.2(\mathrm{qC})^{c}$ \\
\hline 2 & $107.1(\mathrm{qC})$ & $78.7(\mathrm{CH})$ & $123.7(\mathrm{CH})$ & $118.5(\mathrm{CH})$ & $118.3(\mathrm{CH})$ \\
\hline 3 & $121.9(\mathrm{CH})$ & $119.3(\mathrm{CH})$ & $60.8(\mathrm{CH})$ & $126.1(\mathrm{CH})$ & $121.7(\mathrm{CH})$ \\
\hline 4 & $144.2(\mathrm{qC})$ & $146.9(\mathrm{qC})$ & $61.4(\mathrm{qC})$ & $130.5(\mathrm{qC})$ & $133.7(\mathrm{qC})$ \\
\hline 5 & $38.6\left(\mathrm{CH}_{2}\right)$ & $36.8\left(\mathrm{CH}_{2}\right)$ & $36.7\left(\mathrm{CH}_{2}\right)$ & $29.7\left(\mathrm{CH}_{2}\right)$ & $35.7\left(\mathrm{CH}_{2}\right)$ \\
\hline 6 & $25.2\left(\mathrm{CH}_{2}\right)$ & $24.1\left(\mathrm{CH}_{2}\right)$ & $25.3\left(\mathrm{CH}_{2}\right)$ & $81.0(\mathrm{CH})$ & $24.9\left(\mathrm{CH}_{2}\right)$ \\
\hline 7 & $61.0(\mathrm{CH})$ & $60.9(\mathrm{CH})$ & $61.3(\mathrm{CH})$ & $148.0(\mathrm{CH})$ & $61.8(\mathrm{CH})$ \\
\hline 8 & $60.2(\mathrm{qC})$ & $60.6(\mathrm{qC})$ & $60.9(\mathrm{qC})$ & $132.8(\mathrm{qC})$ & $62.9(\mathrm{qC})$ \\
\hline 9 & $39.2\left(\mathrm{CH}_{2}\right)$ & $37.6\left(\mathrm{CH}_{2}\right)$ & $40.1\left(\mathrm{CH}_{2}\right)$ & $25.9\left(\mathrm{CH}_{2}\right)$ & $32.2\left(\mathrm{CH}_{2}\right)$ \\
\hline 10 & $25.8\left(\mathrm{CH}_{2}\right)$ & $26.6\left(\mathrm{CH}_{2}\right)$ & $26.9\left(\mathrm{CH}_{2}\right)$ & $26.2\left(\mathrm{CH}_{2}\right)$ & $39.1\left(\mathrm{CH}_{2}\right)$ \\
\hline 11 & $141.4(\mathrm{CH})$ & $142.7(\mathrm{CH})$ & $141.3(\mathrm{CH})$ & $125.9(\mathrm{CH})$ & $125.6(\mathrm{CH})$ \\
\hline 12 & $133.8(\mathrm{qC})$ & $130.7(\mathrm{qC})$ & $133.1(\mathrm{qC})$ & $133.8(\mathrm{qC})$ & $135.9(\mathrm{qC})$ \\
\hline 13 & $23.2\left(\mathrm{CH}_{2}\right)$ & $24.7\left(\mathrm{CH}_{2}\right)$ & $28.2\left(\mathrm{CH}_{2}\right)$ & $38.2\left(\mathrm{CH}_{2}\right)$ & $22.0\left(\mathrm{CH}_{2}\right)$ \\
\hline 14 & $24.2\left(\mathrm{CH}_{2}\right)$ & $25.9\left(\mathrm{CH}_{2}\right)$ & $27.6\left(\mathrm{CH}_{2}\right)$ & $27.6\left(\mathrm{CH}_{2}\right)$ & $28.4\left(\mathrm{CH}_{2}\right)$ \\
\hline 15 & $64.6(\mathrm{qC})$ & $124.5(\mathrm{qC})$ & $77.8(\mathrm{qC})$ & $33.0(\mathrm{CH})$ & $34.7(\mathrm{CH})$ \\
\hline 16 & $68.9\left(\mathrm{CH}_{2}\right)$ & $174.6(\mathrm{qC})$ & $25.4\left(\mathrm{CH}_{3}\right)$ & $23.4\left(\mathrm{CH}_{3}\right)$ & $22.4\left(\mathrm{CH}_{3}\right)$ \\
\hline 17 & $11.6\left(\mathrm{CH}_{3}\right)$ & $9.1\left(\mathrm{CH}_{3}\right)$ & $25.5\left(\mathrm{CH}_{3}\right)$ & $21.5\left(\mathrm{CH}_{3}\right)$ & $22.1\left(\mathrm{CH}_{3}\right)$ \\
\hline 18 & $16.0\left(\mathrm{CH}_{3}\right)$ & $15.4\left(\mathrm{CH}_{3}\right)$ & $16.4\left(\mathrm{CH}_{3}\right)$ & $68.5\left(\mathrm{CH}_{2}\right)$ & $17.0\left(\mathrm{CH}_{3}\right)$ \\
\hline 19 & $16.1\left(\mathrm{CH}_{3}\right)$ & $16.3\left(\mathrm{CH}_{3}\right)$ & $15.3\left(\mathrm{CH}_{3}\right)$ & $173.6(\mathrm{qC})$ & $63.1\left(\mathrm{CH}_{2}\right)$ \\
\hline 20 & $167.4(\mathrm{qC})$ & $167.5(\mathrm{qC})$ & $167.4(\mathrm{qC})$ & $16.3\left(\mathrm{CH}_{3}\right)$ & $17.2\left(\mathrm{CH}_{3}\right)$ \\
\hline 2-OMe & $49.2\left(\mathrm{CH}_{3}\right)$ & - & - & - & - \\
\hline $15-\mathrm{OMe}$ & - & - & $49.9\left(\mathrm{CH}_{3}\right)$ & - & - \\
\hline $20-\mathrm{OMe}$ & $51.2\left(\mathrm{CH}_{3}\right)$ & $51.9\left(\mathrm{CH}_{3}\right)$ & $51.3\left(\mathrm{CH}_{3}\right)$ & - & - \\
\hline
\end{tabular}

${ }^{a}$ Spectra were measured in $\mathrm{C}_{6} \mathrm{D}_{6}(100 \mathrm{MHz}) ;{ }^{b}$ Spectra were measured in $\mathrm{CDCl}_{3}(100 \mathrm{MHz}) ;{ }^{c}$ Multiplicities are deduced by HSQC and DEPT experiments.

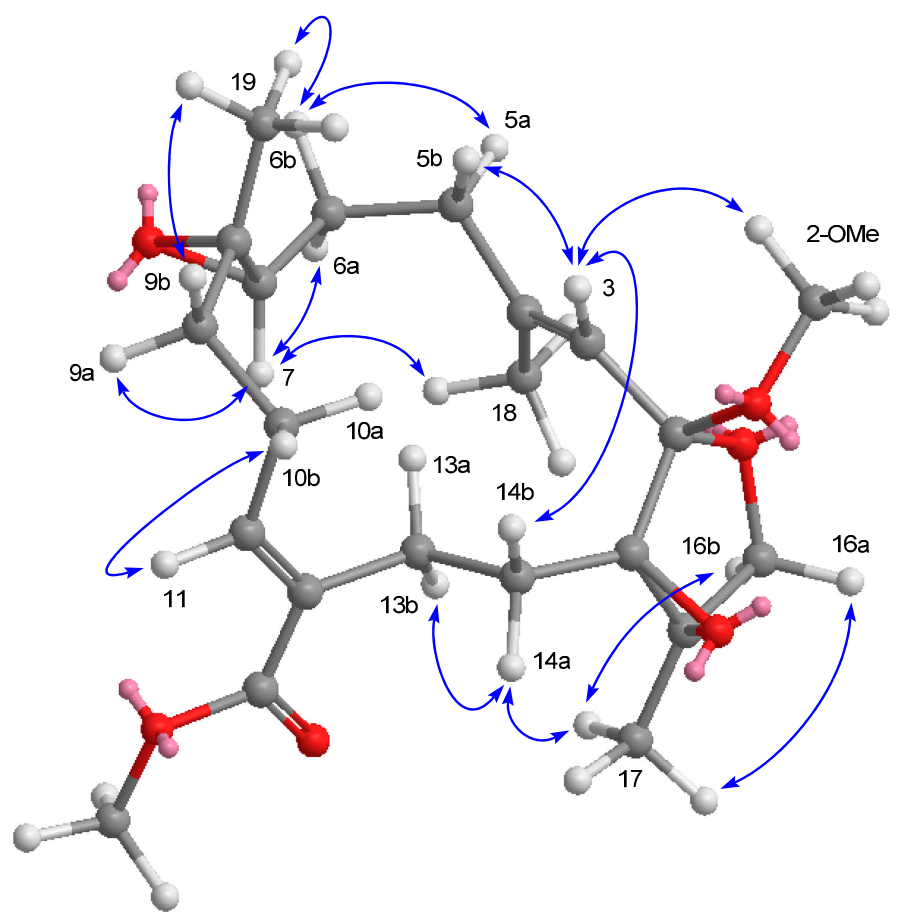

Figure 3. Selected NOESY correlations and computer-generated perspective model using MM2 force field calculations for $\mathbf{1}$. 
The HRESIMS of compound 3 showed a sodiated molecular ion peak at $m / z 401.2301[\mathrm{M}+\mathrm{Na}]^{+}$, which coupled with the ${ }^{13} \mathrm{C}$ NMR data (Table 2), suggested a molecular formula $\mathrm{C}_{22} \mathrm{H}_{34} \mathrm{O}_{5}$ with six indices of hydrogen deficiency. The complete analysis of ${ }^{1} \mathrm{H}-{ }^{1} \mathrm{H}$ COSY, HMBC, and HSQC spectra permitted us to assign all the spectroscopic signals and to propose the planar structure for 3 (Figure 2). The NMR data (Tables 1 and 2) of $\mathbf{3}$ were analogous to those of ehrenberoxide A [4] with the exception that the resonances due to the double bond at C-3 and C-4 $\left[\delta_{\mathrm{H}} 6.10(1 \mathrm{H}, \mathrm{d}, J=10.6 \mathrm{~Hz})\right.$ and $\delta_{\mathrm{C}} 124.3(\mathrm{CH})$ and $\left.136.7(\mathrm{qC})\right]$ in ehrenberoxide $\mathrm{A}$ were replaced by those due to a epoxide $\left[\delta_{\mathrm{H}} 3.53\right.$ $(1 \mathrm{H}, \mathrm{d}, J=8.4 \mathrm{~Hz}) ; \delta_{\mathrm{c}} 60.8(\mathrm{CH})$ and $\left.61.4(\mathrm{qC})\right]$ in 3 . The HMBC correlations (Figure 2) from Me-18 to $\mathrm{C}-3, \mathrm{C}-4$ and $\mathrm{C}-5$ further indicated that the position of the epoxide group at C-3 and C-4. Moreover, the relative configuration of epoxide was assumed to be $3 S^{*}$ and $4 S^{*}$ according to the crucial NOESY correlations between H-2/Me-18, Me-18/H-5a ( $\left.\delta_{\mathrm{H}} 2.02\right)$, Me-18/H-6a $\left(\delta_{\mathrm{H}} 1.83\right), \mathrm{H}-3 / \mathrm{H}-5 \mathrm{~b}\left(\delta_{\mathrm{H}} 1.08\right)$, and $\mathrm{H}-3 / \mathrm{H}-14 \mathrm{a}\left(\delta_{\mathrm{H}} 2.28\right)$ (Figure 4$)$. The $7 S, 8 S$ configuration of epoxide was concluded, consistent with previously reported (+)-12-carboxy-11E-sarcophytoxide for which X-ray crystallography established the absolute configuration [4]. Accordingly, compound 3 was determined unambiguously and defined as 3,4-epoxyehrenberoxide A.

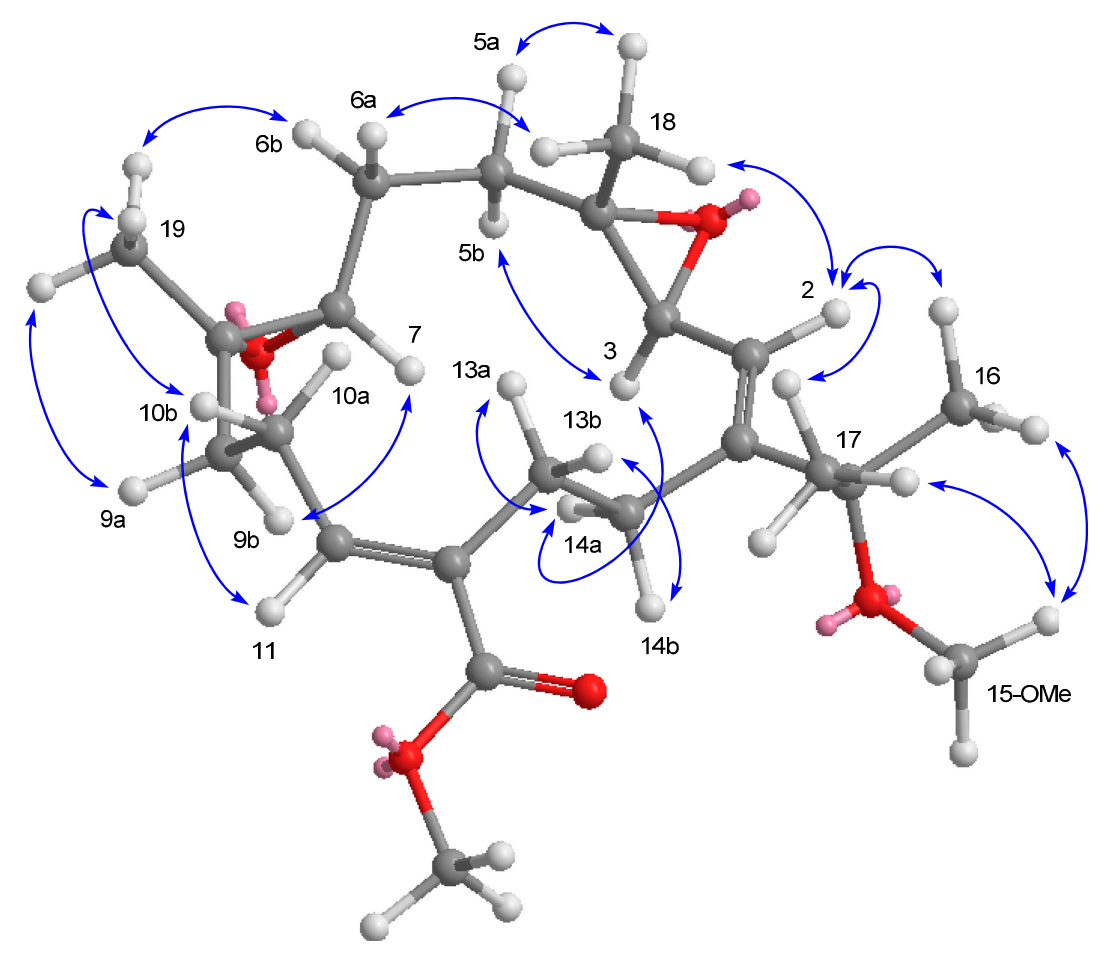

Figure 4. Selected NOESY correlations and computer-generated perspective model using MM2 force field calculations for 3.

Ehrenbergol D (4) analyzed for the molecular formula $\mathrm{C}_{20} \mathrm{H}_{28} \mathrm{O}_{3}$ from its HRESIMS $(\mathrm{m} / z$ 339.1938, $[\mathrm{M}+\mathrm{Na}]^{+}$) and NMR data (Tables 1 and 2), suggesting seven indices of hydrogen deficiency. The IR spectrum of 4 at $3422 \mathrm{~cm}^{-1}$ demonstrated a broad absorption band diagnostic of a primary hydroxyl, which was further identified by the ${ }^{1} \mathrm{H}$ NMR signals at $\delta_{\mathrm{H}} 4.09(1 \mathrm{H}, \mathrm{d}, J=13.6 \mathrm{~Hz}, \mathrm{H}-18 \mathrm{a})$ and 4.03 $(1 \mathrm{H}, \mathrm{d}, J=13.6 \mathrm{~Hz}, \mathrm{H}-18 \mathrm{~b})$, as well as the ${ }^{13} \mathrm{C} \mathrm{NMR}$ signal at $\delta \mathrm{C} 68.5\left(\mathrm{CH}_{2}, \mathrm{C}-18\right)$. The NMR data indicated that 4 possesses four trisubstituted double bonds $\left[\delta_{\mathrm{H}} 5.89(1 \mathrm{H}, \mathrm{d}, J=11.2 \mathrm{~Hz}, \mathrm{H}-2)\right.$; $\delta \mathrm{c} 149.3$ (qC, C-1) and $118.5(\mathrm{CH}, \mathrm{C}-2) ; \delta_{\mathrm{H}} 6.29(1 \mathrm{H}, \mathrm{d}, J=11.2 \mathrm{~Hz}, \mathrm{H}-3) ; \delta_{\mathrm{C}} 126.1(\mathrm{CH}, \mathrm{C}-3)$ and 130.5 
(qC, C-4); $\delta_{\mathrm{H}} 6.83(1 \mathrm{H}, \mathrm{br} \mathrm{s}, \mathrm{H}-7) ; \delta_{\mathrm{c}} 148.0(\mathrm{CH}, \mathrm{C}-7)$ and $132.8(\mathrm{qC}, \mathrm{C}-8) ; \delta_{\mathrm{H}} 4.66(1 \mathrm{H}, \mathrm{br} \mathrm{d}$, $J=10.4 \mathrm{~Hz}, \mathrm{H}-11) ; \delta_{\mathrm{C}} 125.9(\mathrm{CH}, \mathrm{C}-11)$ and $\left.133.8(\mathrm{qC}, \mathrm{C}-12)\right]$. Additionally, the carbon resonance appearing at $\delta_{\mathrm{C}} 173.6$ (qC, $\mathrm{C}$-19) was attributable to an $\alpha, \beta$-unsaturated $\gamma$-lactone carbon. Correlations deduced from extensive analysis of the ${ }^{1} \mathrm{H}-{ }^{1} \mathrm{H}$ COSY correlations of 4 enabled initially the establishment of five partial structures. The connectivity of the above structural fragments was subsequently interconnected by the HMBC correlations (Figure 2). The crucial NOESY correlations between H-2/H-5b ( $\left.\delta_{\mathrm{H}} 2.83\right), \mathrm{H}-2 / \mathrm{Me}-16, \mathrm{H}-2 / \mathrm{Me}-17, \mathrm{H}-3 / \mathrm{Me}-20, \mathrm{H}-5 \mathrm{a}\left(\delta_{\mathrm{H}} 2.87\right) / \mathrm{H}-18 \mathrm{~b}\left(\delta_{\mathrm{H}} 4.03\right)$, $\mathrm{H}-3 / \mathrm{H}-18 \mathrm{a}\left(\delta_{\mathrm{H}} 4.09\right)$ and $\mathrm{H}-3 / \mathrm{H}-14 \mathrm{a}\left(\delta_{\mathrm{H}} 2.68\right)$ (Figure 5) indicated that the geometries of the conjugated diene at $\mathrm{C}-1 / \mathrm{C}-2$ and $\mathrm{C}-3 / \mathrm{C}-4$ were assigned as $E$ and $E$, respectively. The absence of NOESY correlation between H-2 and H-3 and the large coupling constant $\left(J_{2,3}=11.2 \mathrm{~Hz}\right)$ further suggested the s-trans geometry of the conjugated double bonds [4]. The key NOESY correlations between $\mathrm{H}-11$ and $\mathrm{H}-13 \mathrm{~b}\left(\delta_{\mathrm{H}} 2.07\right)$ as well as the $\gamma$-effect of the olefinic methyl signal for $\mathrm{CH}_{3}-20$ $(<20 \mathrm{ppm})[10]$ reflected the $E$ geometry of the trisubstituted double bond at C-11 and C-12 in the molecule. The CD spectrum of 4 exhibited a negative Cotton effect around $\lambda_{\max }(\Delta \varepsilon) 205(-9.0) \mathrm{nm}$ and a positive Cotton effect around $\lambda_{\max }(\Delta \varepsilon) 259(+24.9) \mathrm{nm}$, which matches with the $R$ configuration of model $\alpha, \beta$-unsaturated $\gamma$-lactone [13]. Consequently, ehrenbergol D (4) was designated as $(1 E, 3 E, 6 R, 7 Z, 11 E)$-18-hydroxycembra-1,3,7,11-tetraen-6,19-olide.

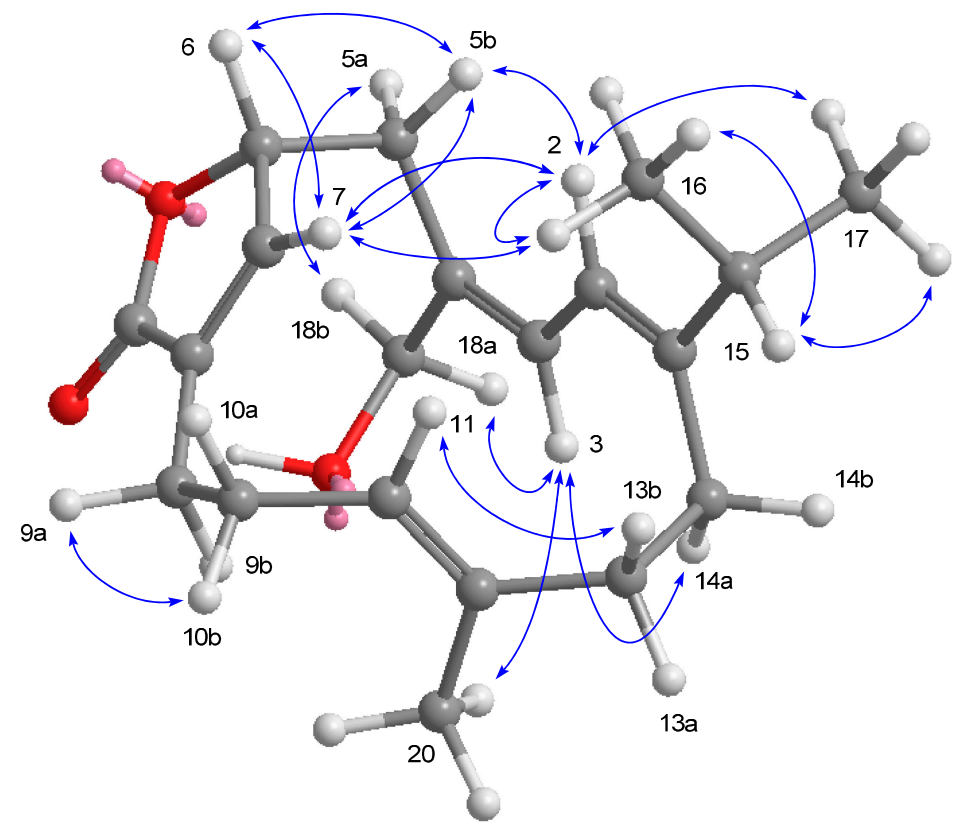

Figure 5. Selected NOESY correlations and computer-generated perspective model using MM2 force field calculations for 4.

Ehrenbergol E (5) was assigned a molecular formula $\mathrm{C}_{20} \mathrm{H}_{32} \mathrm{O}_{2}$, according to its HRESIMS and NMR spectroscopic data (Tables 1 and 2). The decided assignment of $\mathbf{5}$ was established by the interpretation of ${ }^{1} \mathrm{H}^{-1} \mathrm{H}$ COSY and HMBC correlations. The ${ }^{1} \mathrm{H}^{-13} \mathrm{C}$ long-range correlations as determined from the HMBC spectrum allowed the connectivity of the structural fragments around each methyl group to be deduced. The configurations of all double bonds were confirmed from a NOESY experiment on 5. The presence of a key NOESY correlation between the vinylic $\mathrm{H}-11\left(\delta_{\mathrm{H}} 5.08\right)$ and $\mathrm{H}-13 \mathrm{~b}\left(\delta_{\mathrm{H}} 2.04\right)$ made it possible to identify the configuration of the olefin at $\mathrm{C}-11 / \mathrm{C}-12$ as 
$E$ geometry. The geometries of the conjugated diene at $\mathrm{C}-1 / \mathrm{C}-2$ and $\mathrm{C}-3 / \mathrm{C}-4$ were assigned as $E$ and $E$ on the basis of the crucial NOESY correlations between $\mathrm{H}-2\left(\delta_{\mathrm{H}} 6.07\right) / \mathrm{Me}-16\left(\delta_{\mathrm{H}} 1.06\right), \mathrm{H}-2 / \mathrm{Me}-18$ $\left(\delta_{\mathrm{H}} 1.76\right)$, and $\mathrm{H}-3\left(\delta_{\mathrm{H}} 5.98\right) / \mathrm{H}-5 \mathrm{a}\left(\delta_{\mathrm{H}} 2.28\right)$. The absence of NOESY correlation between $\mathrm{H}-2$ and $\mathrm{H}-3$ and the large coupling constant $\left(J_{2,3}=10.8 \mathrm{~Hz}\right)$ further suggested the s-trans geometry of the conjugated double bonds [4]. Based on the similarity of the crucial NOESY correlations, the absolute configurations at C-7 and C-8 of $\mathbf{5}$ were assumed to be identical with those of compounds $\mathbf{1}-\mathbf{3}$. The ${ }^{1} \mathrm{H}$ and ${ }^{13} \mathrm{C}$ NMR spectroscopic data (Tables 1 and 2) of 5 were in full agreement with those of an $7 R, 8 S$-epoxy enantiomer, which had been prepared as an intermediate in an enantioselective total synthesis of (-)-7,8-epoxy-7,8-dihydrocembrene-C [14]. However, the specific rotation $[\alpha]^{25} \mathrm{D}+40.0$ $\left(c 0.5, \mathrm{CHCl}_{3}\right)$ of 5 was substantially different from that of the $7 R, 8 S$ enantiomer, $[\alpha]^{20}{ }_{\mathrm{D}}-41.7(c 0.35$, $\mathrm{CHCl}_{3}$ ), suggesting that the absolute configurations of 7,8-epoxy group in $\mathbf{5}$ should be $7 S$ and $8 R$. The full assignments of ehrenbergol E (5) have been disclosed (Tables 1 and 2) by extensive 2D NMR spectroscopic data analyses for the first time.

Macrocyclic cembranoids and their derivatives, distributed mainly in the soft corals belonging to the genus Sarcophyton (Alcyoniidae), have attracted much attention from chemists due to their structural complexity and remarkable biological activities such as antitumor [15-21], ichthyotoxic [22], anti-inflammatory [23], anti-osteoporotic [24], neuroprotective [25], antiangiogenic [26], antimetastatic [26], and antibacterial properties [27]. Our previous studies have reported that macrocyclic cembranoids possess antiviral and cytotoxic properties [4-6], which prompted us to evaluate the cytotoxicity against P-388, A-459, HT-29, and HEL cells as well as antiviral activity against HCMV cells of compounds 1-5.

Preliminary cytotoxic screening revealed that $\mathbf{4}$ and $\mathbf{5}$ displayed cytotoxicity against P-388 cell line with $\mathrm{EC}_{50}$ values of 2.0 and $3.0 \mu \mathrm{M}$, respectively. However, the other tested compounds were not cytotoxic to P-388, A-549, HT-29 and HEL cells. Compounds 1-5 were examined for antiviral activity against human cytomegalovirus (HCMV) using a human embryonic lung (HEL). At a concentration of $1 \mu \mathrm{g} / \mathrm{mL}$, compound 2 showed slight antiviral activity against HCMV cells with an $\mathrm{IC}_{50}$ value of $45.0 \mu \mathrm{g} / \mathrm{mL}$. With the exception of the above findings, the obtained negative results showed that the others exhibited no discernible activity against HCMV cells $\left(\mathrm{IC}_{50}>50 \mu \mathrm{g} / \mathrm{mL}\right.$ ). According to our studies, the cembrane-type derivatives endowed with various biological activities and $S$. ehrenbergi identified as a potential marine source for the discovery of promising new drugs. Advanced bioactivity assays and chemical modifications for these compounds will be carried out if sufficient material can be recollected from the marine organism.

\section{Experimental Section}

\subsection{General Experimental Procedures}

Optical rotations were determined with a JASCO P1020 digital polarimeter (Tokyo, Japan). Ultraviolet (UV) and infrared (IR) spectra were obtained on a JASCO V-650 (Tokyo, Japan) and JASCO FT/IR-4100 spectrometer (Tokyo, Japan), respectively. CD analysis was performed on a JASCO J-815 spectropolarimeter (Tokyo, Japan). The NMR spectra were recorded on a Varian MR 400 NMR spectrometer (Santa Clara, CA, USA) at $400 \mathrm{MHz}$ for ${ }^{1} \mathrm{H}$ and $100 \mathrm{MHz}$ for ${ }^{13} \mathrm{C}$, respectively. 
Chemical shifts are expressed in $\delta(\mathrm{ppm})$ referring to the solvent peaks $\delta \mathrm{H} 7.15$ and $\delta_{\mathrm{C}} 128.5$ for $\mathrm{C}_{6} \mathrm{D}_{6}$, and $\delta_{\mathrm{H}} 7.27$ and $\delta_{\mathrm{C}} 77.0$ for $\mathrm{CDCl}_{3}$, respectively, and coupling constants are expressed in Hz. ESIMS were recorded by ESI FT-MS on a Bruker APEX II mass spectrometer (Bremen, Germany). Silica gel 60 (Merck, Darmstadt, Germany, 230-400 mesh), Sephadex LH-20 (Amersham Pharmacia Biotech., Piscataway, NJ, USA), and LiChroprep RP-18 (Merck, 40-63 $\mu \mathrm{m}$ ) were used for column chromatography. Precoated silica gel plates (Merck, Kieselgel $60 \mathrm{~F}_{254}, 0.25 \mathrm{~mm}$ ) and precoated RP-18 F254s plates (Merck, 1.05560) were used for TLC analyses. High-performance liquid chromatography (HPLC) was performed on a Hitachi L-7100 pump (Tokyo, Japan) equipped with a Hitachi L-7400 UV detector at $220 \mathrm{~nm}$ and a semi-preparative reversed-phase column (Merck, Hibar Purospher RP-18e, $5 \mu \mathrm{m}, 250 \times 10 \mathrm{~mm}$ ).

\subsection{Animal Material}

Specimens of $S$. ehrenbergi were collected at the San-Hsian-Tai, Taitong County, Taiwan, in July 2009, at a depth of $6 \mathrm{~m}$, and were frozen immediately after collection. Identification was kindly verified by Prof. Chang-Feng Dai, Institute of Oceanography, National Taiwan University (Taipei, Taiwan). A voucher specimen (ST-13) is available for inspection at the Department of Marine Biotechnology and Resources, National Sun Yat-sen University, Kaohsiung, Taiwan.

\subsection{Extraction and Isolation}

The frozen material $(4.0 \mathrm{~kg})$ was cut into small pieces and extracted exhaustively with acetone $(4 \times 3 \mathrm{~L})$ at room temperature. The combined acetone extracts were concentrated to a brown gum, which was partitioned between $\mathrm{H}_{2} \mathrm{O}$ and EtOAc. The resulting EtOAc extract was concentrated under reduced pressure to give a dark brown residue $(46.9 \mathrm{~g})$, which was fractionated by gradient Si-60 gel column chromatography eluting with a step gradient $(0 \%-100 \%$ EtOAc in $n$-hexane) to yield 20 fractions. Fraction 14 (3.6 g) eluted with $n$-hexane-EtOAc (2:1) was subjected to column chromatography on silica gel using $n$-hexane-EtOAc mixtures of increasing polarity for elution to give 10 subfractions. A subfraction 14-4 (0.7 g) eluted with $n$-hexane-EtOAc (6:1) was subjected to a RP-18 gravity column using 60\% MeOH in $\mathrm{H}_{2} \mathrm{O}, 70 \% \mathrm{MeOH}$ in $\mathrm{H}_{2} \mathrm{O}, 80 \% \mathrm{MeOH}$ in $\mathrm{H}_{2} \mathrm{O}, 90 \%$ $\mathrm{MeOH}$ in $\mathrm{H}_{2} \mathrm{O}$, and $100 \% \mathrm{MeOH}$, respectively. Altogether, 5 subfractions were obtained, of which subfraction 14-4-3 (80 mg) was further purified by RP-18 HPLC (85\% $\mathrm{MeOH}$ in $\left.\mathrm{H}_{2} \mathrm{O}\right)$ to afford 5 $(5.1 \mathrm{mg})$. Similarly, fraction $16(2.0 \mathrm{~g})$ eluted with $n$-hexane-EtOAc (1:2) was subjected to a silica gel column using $n$-hexane-EtOAc gradient (10:1 to $1: 10)$ for elution to give 11 subfractions. A subfraction 16-3 (108 mg) eluted with $n$-hexane-EtOAc (10:1) was applied to a RP-18 gravity column $\left(\mathrm{MeOH} / \mathrm{H}_{2} \mathrm{O}, 50: 50\right.$ to $\left.100 \% \mathrm{MeOH}\right)$ to separate 6 subfractions. Subsequently, a subfraction 16-3-3 (13 mg) was purified by RP-18 HPLC (70\% MeOH in $\left.\mathrm{H}_{2} \mathrm{O}\right)$ to obtain 3 (4.9 mg). A subfraction 16-6 (597 mg) eluted with $n$-hexane-EtOAc (4:1) was chromatographed on a RP-18 gravity column $\left(\mathrm{MeOH} / \mathrm{H}_{2} \mathrm{O}, 50: 50\right.$ to $\left.100 \% \mathrm{MeOH}\right)$ to separate 6 subfractions. Subsequently, a subfraction 16-6-2 $(13 \mathrm{mg})$ was purified by RP-18 HPLC $\left(65 \% \mathrm{MeOH}\right.$ in $\left.\mathrm{H}_{2} \mathrm{O}\right)$ to give $2(1.2 \mathrm{mg})$. A subfraction 16-7 (598 mg) was applied to column chromatography on RP-18 gravity column using $70 \% \mathrm{MeOH}$ in $\mathrm{H}_{2} \mathrm{O}$ to afford a mixture $(109 \mathrm{mg})$ that was further purified by RP-18 HPLC $\left(70 \% \mathrm{MeOH}\right.$ in $\left.\mathrm{H}_{2} \mathrm{O}\right)$ to afford $4(2.9 \mathrm{mg})$. Similarly, fraction 17 (1.8 g) eluted with $n$-hexane-EtOAc (1:4) was fractioned by column 
chromatography on silica gel column using $n$-hexane with increasing amounts of EtOAc, to fractionate 10 subfractions. Then, a subfraction $17-7(327 \mathrm{mg})$ eluted with $n$-hexane-EtOAc (1:1) was applied to a RP-18 gravity column $\left(\mathrm{MeOH} / \mathrm{H}_{2} \mathrm{O}, 50: 50\right.$ to $\left.100 \% \mathrm{MeOH}\right)$ to give 6 subfractions. A subfraction 17-7-4 (31 mg) was subjected to RP-18 HPLC $\left(80 \% \mathrm{MeOH}\right.$ in $\left.\mathrm{H}_{2} \mathrm{O}\right)$ to afford a mixture $(3.2 \mathrm{mg})$ that was further purified by a short silica gel column using $n$-hexane-EtOAc (6:1) to provide 1 (3.3 mg).

(+)-1,15-Epoxy-2-methoxy-12-methoxycarbonyl-11E-sarcophytoxide (1): Colorless, viscous oil; $[\alpha]^{25} \mathrm{D}+71\left(c\right.$ 0.3, $\left.\mathrm{CHCl}_{3}\right) ; \mathrm{UV}(\mathrm{MeOH}) \lambda_{\max }(\log \varepsilon) 225(3.83) \mathrm{nm} ; \mathrm{IR}(\mathrm{KBr}) v_{\max } 2962,1712,1457$, 1373, 1263, 1088, $1027 \mathrm{~cm}^{-1} ;{ }^{1} \mathrm{H}$ NMR and ${ }^{13} \mathrm{C}$ NMR data, see Tables 1 and 2; ESIMS $m / z 415$ $[\mathrm{M}+\mathrm{Na}]^{+}$; HRESIMS $m / z 415.2093[\mathrm{M}+\mathrm{Na}]^{+}$(calcd for $\mathrm{C}_{22} \mathrm{H}_{32} \mathrm{O}_{6} \mathrm{Na}, 415.2096$ ) (Figures $\mathrm{S} 1-\mathrm{S} 6$ ).

(+)-2-epi-12-Methoxycarbonyl-11E-sarcophine (2): Colorless, viscous oil; $[\alpha]^{25} \mathrm{D}+56$ (c 0.1 , $\left.\mathrm{CHCl}_{3}\right)$; UV (MeOH) $\lambda_{\max }(\log \varepsilon) 224$ (3.89) nm; IR (KBr) $v_{\max } 2926,1751,1712,1701,1636,1576$, 1436, 1386, 1244, 1109, 1125, $1099 \mathrm{~cm}^{-1}$; CD $\left(2.67 \times 10^{-4} \mathrm{M}, \mathrm{MeOH}\right) \lambda_{\max }(\Delta \varepsilon) 279(+6.8), 245$ $(-1.1)$ and $215(-2.9) \mathrm{nm} ;{ }^{1} \mathrm{H}$ NMR and ${ }^{13} \mathrm{C}$ NMR data, Tables 1 and 2; ESIMS $m / z 383[\mathrm{M}+\mathrm{Na}]^{+}$; HRESIMS $m / z 383.1832[\mathrm{M}+\mathrm{Na}]^{+}$(calcd for $\mathrm{C}_{21} \mathrm{H}_{28} \mathrm{O}{ }_{5} \mathrm{Na}, 383.1834$ ) (Figures $\mathrm{S} 7-\mathrm{S} 12$ ).

3,4-Epoxyehrenberoxide A (3): Colorless, viscous oil; $[\alpha]^{25} \mathrm{D}+23\left(c 0.5, \mathrm{CHCl}_{3}\right)$; UV (MeOH) $\lambda_{\max }$ $(\log \varepsilon) 226(3.85) \mathrm{nm}$; IR $(\mathrm{KBr}) v_{\max }$ 2951, 1715, 1643, 1461, 1376, 1179, 1279, 1240, 1195, $1073 \mathrm{~cm}^{-1}$; ${ }^{1} \mathrm{H}$ NMR and ${ }^{13} \mathrm{C}$ NMR data, see Tables 1 and 2; ESIMS $m / z 401[\mathrm{M}+\mathrm{Na}]^{+}$; HRESIMS $m / z 401.2301[\mathrm{M}+\mathrm{Na}]^{+}$(calcd for $\mathrm{C}_{22} \mathrm{H}_{34} \mathrm{O}_{5} \mathrm{Na}, 401.2304$ ) (Figures $\mathrm{S} 13-\mathrm{S} 18$ ).

Ehrenbergol D (4): Colorless, viscous oil; $[\alpha]^{25} \mathrm{D}+35$ (c 0.3, $\left.\mathrm{CHCl}_{3}\right) ; \mathrm{UV}(\mathrm{MeOH}) \lambda_{\max }(\log \varepsilon) 245$ (3.67) nm; IR (KBr) $v_{\max } 3422,2959,1747,1621,1438,1383,1219,1041 \mathrm{~cm}^{-1}$; CD $\left(9.76 \times 10^{-4} \mathrm{M}\right.$, $\mathrm{MeOH}) \lambda_{\max }(\Delta \varepsilon) 259(+24.9)$ and $205(-9.0) \mathrm{nm} ;{ }^{1} \mathrm{H}$ NMR and ${ }^{13} \mathrm{C}$ NMR data, see Tables 1 and 2; ESIMS $m / z 339\left[\mathrm{M}+\mathrm{Na}^{+}\right.$; HRESIMS $m / z 339.1938[\mathrm{M}+\mathrm{Na}]^{+}\left(\right.$calcd for $\mathrm{C}_{20} \mathrm{H}_{28} \mathrm{O} 3 \mathrm{Na}, 339.1936$ ) (Figures S19-S24).

Ehrenbergol E (5): Colorless, viscous oil; $[\alpha]^{25} \mathrm{D}+40\left(c\right.$ 0.5, $\left.\mathrm{CHCl}_{3}\right)$; UV (MeOH) $\lambda_{\max }(\log \varepsilon) 249$ (3.76) nm; IR (KBr) $v_{\max } 3441,2958,2932,1619,1455,1376,1240,1033 \mathrm{~cm}^{-1} ;{ }^{1} \mathrm{H} \mathrm{NMR}$ and ${ }^{13} \mathrm{C}$ NMR data, see Tables 1 and 2; ESIMS $m / z 327[\mathrm{M}+\mathrm{Na}]^{+}$; HRESIMS $m / z 327.2303[\mathrm{M}+\mathrm{Na}]^{+}$ (calcd for $\mathrm{C}_{20} \mathrm{H}_{32} \mathrm{O}_{2} \mathrm{Na}, 327.2300$ ) (Figures $\mathrm{S} 25-\mathrm{S} 30$ ).

\subsection{Cytotoxicity Assay}

Cytotoxicity was determined against P-388 (mouse lymphocytic leukemia), HT-29 (human colon adenocarcinoma), and A-549 (human lung epithelial carcinoma) tumor cells using a modification of the MTT colorimetric method. The provision of the P-388 cell line was supported by John M. Pezzuto, formerly of the Department of Medicinal Chemistry and Pharmacognosy, University of Illinois at Chicago, IL, USA. These HT-29 and A-549 cell lines were purchased from the American Type Culture Collection (Manassas, VA, USA). The anticancer agent mithramycin was used as the positive control and exhibited $\mathrm{EC}_{50}$ values of $0.05,0.06$ and $0.07 \mu \mathrm{M}$ against P-388, A-549 and HT-29, respectively. The experimental details of this assay were carried out according to a previously described procedure [28,29]. 


\subsection{Anti-HCMV Assay}

To determine the effects of the natural product upon human cytomegalovirus (HCMV) cytopathic effect (CPE), confluent human embryonic lung (HEL) cells grown in 24-well plates were incubated for $1 \mathrm{~h}$ in the presence or absence of various concentrations of tested natural product. Ganciclovir was used as a positive control. Then, cells were infected with HCMV at an input of 1000 pfu (plaque forming units) per well of 24-well dish. Antiviral activity is expressed as IC50 (50\% inhibitory concentration), or compound concentration required to reduce virus induced CPE by $50 \%$ after 7 days as compared with the untreated control. To monitor the cell growth upon treating with natural products, an MTT-colorimetric assay was employed [30].

\section{Conclusions}

Five new polyoxygenated cembranoids 1-5 were successfully purified from Sarcophyton ehrenbergi. Preliminary cytotoxic screening revealed that compounds 1-3 were not cytotoxic to P-388, A-549, HT-29 and HEL cells. However, compounds $\mathbf{4}$ and $\mathbf{5}$ displayed cytotoxicity against P-388 with EC50 values of 2.0 and $3.0 \mu \mathrm{M}$, respectively. The result may suggest that the conjugated double bonds at C-1/C-2 and C-3/C-4 are important for the cytotoxicity against P-388. Additionally, at a concentration of $1 \mu \mathrm{g} / \mathrm{mL}$, compound 2 showed slight antiviral activity against $\mathrm{HCMV}$ with an $\mathrm{IC}_{50}$ value of $25.0 \mu \mathrm{g} / \mathrm{mL}$.

\section{Supplementary Materials}

Supplementary materials can be found at http://www.mdpi.com/1422-0067/16/03/6140/s1.

\section{Acknowledgments}

This work was supported by grants from NSYSU-KMU Joint Project (NSYSUKMU 104-P023) and Ministry of Science and Technology (NSC 102-2320-B-110-003-MY3).

\section{Author Contributions}

Conceived and designed the experiments: Chang-Yih Duh, Shang-Kwei Wang; Performed the experiments: Mu-Keng Hsieh, Shang-Kwei Wang; Analyzed the data: Chang-Yih Duh, Shi-Yie Cheng.

\section{Conflicts of Interest}

The authors declare no conflict of interest.

\section{References}

1. Bowden, B.F.; Coll, J.C.; Hicks, W.; Kazlauskas, R.; Mitchell, S.J. Studies of Australian soft corals. X. The isolation of epoxyisoneocembrene-A from Sinularia grayi and isoneocembrene-A from Sarcophyton ehrenbergi. Aust. J. Chem. 1978, 31, 2707-2712. 
2. König, G.M.; Wright, A.D. New cembranoid diterpenes from the soft coral Sarcophyton ehrenbergi. J. Nat. Prod. 1998, 61, 494-496.

3. Shaker, K.H.; Mueller, M.; Ghani, M.A.; Dahse, H.M.; Seifert, K. Terpenes from the soft corals Litophyton arboreum and Sarcophyton ehrenbergi. Chem. Biodivers. 2010, 7, 2007-2015.

4. Cheng, S.-Y.; Wang, S.-K.; Chiou, S.-F.; Hsu, C.-H.; Dai, C.-F.; Chiang, M.Y.; Duh, C.-Y. Cembranoids from the octocoral Sarcophyton ehrenbergi. J. Nat. Prod. 2010, 73, 197-203.

5. Wang, S.-K.; Hsieh, M.-K.; Duh, C.-Y. Three new cembranoids from the Taiwanese soft coral Sarcophyton ehrenbergi. Mar. Drugs 2012, 10, 1433-1444.

6. Wang, S.-K.; Hsieh, M.-K.; Duh, C.-Y. New diterpenoids from soft coral Sarcophyton ehrenbergi. Mar. Drugs 2013, 11, 4318-4327.

7. Elkhateeb, A.; El-Beih, A.A.; Gamal-Eldeen, A.M.; Alhammady, M.A.; Ohta, S.; Paré, P.W.; Hegazy, M.F. New terpenes from the Egyptian soft coral Sarcophyton ehrenbergi. Mar. Drugs 2014, 12, 1977-1986.

8. Piel, J. Bacterial symbionts: Prospects for the sustainable production of invertebrate-derived pharmaceuticals. Curr. Med. Chem. 2006, 13, 39-50.

9. Roengsumran, S.; Achayindee, S.; Petsom, A.; Pudhom, K.; Singtothong, P.; Surachetapan, C.; Vilaivan, T. Two new cembranoids from Croton oblongifolius. J. Nat. Prod. 1998, 61, 652-654.

10. Iwashima, M.; Matsumoto, Y.; Takenaka, Y.; Iguchi, K.; Yamori, T. New marine diterpenoids from the Okinawan soft coral Clavularia koellikeri. J. Nat. Prod. 2002, 65, 1441-1446.

11. Rodriguez, A.D.; Li, Y.; Dhasmana, H.; Barnes, C. New marine cembrane diterpenoids isolated from the Caribbean gorgonian Eunicea mammosa. J. Nat. Prod. 1993, 56, 1101-1113.

12. Pham, N.B.; Butler, M.S.; Quinn, R.J. Naturally occurring cembranes from an Australian Sarcophyton species. J. Nat. Prod. 2002, 65, 1147-1150.

13. Gawronski, J.K.; Oeveren, A.; Deen, H.; Leung, C.W.; Feringa, B.L. Simple circular dichroic method for the determination of absolute configuration of 5 -substituted $2(5 H)$-furanones. J. Org. Chem. 1996, 61, 1513-1515.

14. Liu, Z.; Li, W.Z.; Peng, L.; Li, Y.; Li, Y. First enantioselective total synthesis of (natural) (+)-11,12-epoxy-11,12-dihydrocembrene-C and (-)-7,8-epoxy-7,8-dihydrocembrene-C. $J$. Chem. Soc. Perkin Trans. 2000, 24, 4250-4257.

15. Gross, H.; Wright, A.D.; Beil, W.; König, G.M. Two new bicyclic cembranolides from a new Sarcophyton species and determination of the absolute configuration of sarcoglaucol-16-one. Org. Biomol. Chem. 2004, 2, 1133-1138.

16. Huang, H.-C.; Ahmed, A.F.; Su, J.-H.; Chao, C.-H.; Wu, Y.-C.; Chiang, M.Y.; Sheu, J.-H. Crassocolides A-F, new cembranoids with a trans-fused lactone from the soft coral Sarcophyton crassocaule. J. Nat. Prod. 2006, 69, 1554-1559.

17. Zhang, C.; Li, J.; Su, J.; Liang, Y.; Yang, X.; Zheng, K.; Zeng, L. Cytotoxic diterpenoids from the soft coral Sarcophyton crassocaule. J. Nat. Prod. 2006, 69, 1476-1480.

18. Feller, M.; Rudi, A.; Berer, N.; Goldberg, I.; Stein, Z.; Benayahu, Y.; Schleyer, M.; Kashman, Y. Isoprenoids of the soft coral Sarcophyton glaucum: Nyalolide, a new biscembranoid, and other terpenoids. J. Nat. Prod. 2004, 67, 1303-1308. 
19. El Sayed, K.A.; Hamann, M.T.; Waddling, C.A.; Jensen, C.; Lee, S.K.; Dunstan, C.A.; Pezzuto, J.M. Structurally novel bioconversion products of the marine natural product sarcophine effectively inhibit JB6 cell transformation. J. Org. Chem. 1998, 63, 7449-7455.

20. Yan, X.-H.; Gavagnin, M.; Cimino, G.; Guo, Y.-W. Two new biscembranes with unprecedented carbon skeleton and their probable biogenetic precursor from the Hainan soft coral Sarcophyton latum. Tetrahedron Lett. 2007, 48, 5313-5316.

21. Cheng, Y.-B.; Shen, Y.-C.; Kuo, Y.-H.; Khalil, A.T. Cembrane diterpenoids from the Taiwanese soft coral Sarcophyton stolidotum. J. Nat. Prod. 2008, 71, 1141-1145.

22. Iwagawa, T.; Nakamura, S.; Masuda, T.; Okamura, H.; Nakatani, M.; Siro, M. Irregular cembranoids containing a 13-membered carbocyclic skeleton isolated from a soft coral, Sarcophyton species. Tetrahedron 1995, 51, 5291-5298.

23. Sawant, S.; Youssef, D.; Mayer, A.; Sylvester, P.; Wali, V.; Arant, M.; el Sayed, K.A. Anticancer and anti-inflammatory sulfur-containing semisynthetic derivatives of sarcophine. Chem. Pharm. Bull. 2006, 54, 1119-1123.

24. Cuong, N.X.; Tuan, T.A.; Kiem, P.V.; Minh, C.V.; Choi, E.M.; Kim, Y.H. New cembranoid diterpenes from the Vietnamese soft coral Sarcophyton mililatensis stimulate osteoblastic differentiation in MC3T3-E1 cells. Chem. Pharm. Bull. 2008, 56, 988-992.

25. Badria, F.A.; Guirguis, A.N.; Perovic, S.; Steffen, R.; Müller, W.E.G.; Schröder, H.C. Sarcophytolide: A new neuroprotective compound from the soft coral Sarcophyton glaucum. Toxicology 1998, 131, 133-143.

26. Sawant, S.; Youssef, D.; Reiland, J.; Ferniz, M.; Marchtti, D.; El Sayed, K.A. Biocatalytic and antimetastatic studies of the marine cembranoids sarcophine and 2-epi-16-deoxysarcophine. J. Nat. Prod. 2006, 69, 1010-1013.

27. Bishara, A.; Rudi, A.; Benayahu, Y.; Kashman, Y. Three biscembranoids and their monomeric counterpart cembranoid, a biogenetic Diels-Alder precursor, from the soft coral Sarcophyton elegans. J. Nat. Prod. 2007, 70, 1951-1954.

28. Geran, R.I.; Greenberg, N.H.; MacDonald, M.M.; Schumacher, A.M.; Abbott, B.J. Protocols for screening chemical agents and natural products against animal tumors and other biological syatems. Cancer Chemother. Rep. 1972, 3, 1-91.

29. Hou, R.-S.; Duh, C.-Y.; Chiang, M.Y.; Lin, C.-N. Sinugibberol, a new cytotoxic cembranoid diterpene from the soft coral Sinularia gibberosa. J. Nat. Prod. 1995, 58, 1126-1130.

30. Stevens, M.; Balzarini, J.; Tabarrini, O.; Andrei, G.; Snoeck, R.; Cecchetti, V.; Fravolini, A.; de Clercq, E.; Pannecouque, C. Cell-dependent interference of a series of new 6-aminoquinolone derivatives with viral (HIV/CMV) transactivation. J. Antimicrob. Chemother. 2005, 56, 847-855.

(C) 2015 by the authors; licensee MDPI, Basel, Switzerland. This article is an open access article distributed under the terms and conditions of the Creative Commons Attribution license (http://creativecommons.org/licenses/by/4.0/). 